Association, printed in the twelfth Annual Report, 1886 , I feel impelled, on at length receiving to-day, at this frontier outpost of scientific civilisation, a copy, long ordered, of the Association's "Plane Geometry," Part 2, to say a few words suggested by it, favouring accord in these fundamental matters.

The very first definition and first theorem show the glaring need in English for a word which the Germans have in Strecke. Such a word, meaning a piece of a straight line, is needed in the first definition, the definition of a circle, for all straight lines are infinite in size, and radii are pieces of straight lines, and not whole straight lines. This is unconsciously recognised, even in the first theorem, where for " piece of a straight line" the undefined word distance is used, inappropriate because of its association with ideas of measurement by a unit and length, and because of its different and confusing use in the phrase "shortest distance."

In the demonstration of this first theorem, "straight line" is used it its proper sense, though just before, in the first definition, it was bunglingly used in the sense here given to distance. For the part of a straight line between two definite points I have long used the word "sect," which, carried over to the sphere with the meaning part of the spherical line less than half, gives the key to two-dimensional spherics.

And this suggests another objection to the same first defini. tion. It says a circle is a plane figure. Now one cannot even think of spherics without seeing how immeasurably better it is to define a circle as a curve. It will be so defined as soon as the student reaches analytics, so why have him learn something only to unlearn?

In the fourth definition we have an over-used word, "conjugate." Two arcs which together make a circle should be called explemenlat. Explement is a natural third to complement and supplement. Again converse is a term of lugic, and does not mean what it is here used to mean, that is, inverse.

In the introductory remarks to the fourth book I think it is a mistake to call hunger, love, courage, talent, wisdom, magni. tutes.

A magnitude is whatever can be added to itself, so as to double. The very first sentence says : "In this book the subjects of the propositions . . . are magnitudes in general ;" but the whole treatment is founded upon multiples, and is only applicable where multiples can be made. Not only must we have an exact criterion of equality, we must be able to add without shrinkage.

A little farther on we meet the absurd statement, "Funda mentally, number is conting:"

Now we know that counting is establishing $z$ one-to-one correspondence between the individuals of an aggregate and of a standard group which was primarily the fingers. But a number is fundamentally a picture of an aggregate which for all counting purposes is as good as the aggregate itself-a picture consisting of a mark for each distinct individual in the aggregate, as III. ; and then secondarily a symbol for that picture, as 3 .

It is questionable whether $\mathbb{B}$ ook IV. Part $I$, has any vali 1 excuse for cxisting. Proportion for commensurable magnitudes neither calls for nor warrants treatment by multiples. Sandeman, in the preface to his "Pelicotetics," speaks of "the phenomenon of incommensurability, through which alone arises any need of ratio, either the thing or the name." Euclid's marvellously elegant treatment of proportion is only admirable beccause of the difficulty it so deftly overcomes. To use it on commensurables is to use a Gatling gun on a plucked chicken. The illustration given under Definition 4 of this Part I (which definition needs the word commensurable inserted in it), " 4 halfcrowns $=5$ florins," reminds one how badly England needs a decimal sysiem of coinage, weights, and measures. No light is thrown on the compounding of ratios, but the error of A. J Ellis is avoided. He says: "The ratio of B to A means the order in which the multiples of B are distributed among those of A."

These are points suggested in first turning the leaves of a new book of most gratifying soundness. May it ward off from England the misfortune America now suffers, in that our most popnlar book on geometry makes the fundamental blunder of basing the treatment of parallels on direction, uses in its proofs the stultifying formula, "a straight line is the shortest distance between two points," and from one end to the other makes us wish for an American Association for the Improvement of Geometrical Teaching.

['niversity of Texas, Austin, Texas, March 3
The Svastika as both Sun and Fire Symbol

The late Prof. Dr. Worsaae ("Industrial Arts of Old Den mark") claims the ring-cross

symbol, and a small cup-shaped hollow for the moon; both these he places as belonging to the later Stone Age of Scandi navia, and, apparently, the only recognised emblems of that period. He observes, in one place: "How many hundred years, or, indeed, how many thousand years, before the Christian era the earlier Stone Age began, it is impossible to say."

The same writet places amongst the emblems of the later

Bronze Age the wheel-cross (B) the chariot wheel of the

sun ?). To this day, both in Denmark, Holland, and in parts of Germany, a wheel is frequently placed on the roof of a stable or other building, which is thus deemed protected from fire, especially if a stork can be induced to make its nest upon the wheel. The stork, owing to his red legs, was not inajtly considered an emblem of fire; he was also the herald of summerhe brought light and warmth. The Moqui symbol for the sun (as described by Dr. Dryer in Nature, Feb. Io, p. 345) exists also on articles classed by Prof. Worsaae as belonging to the later Bronze Age in Scandinavia, with the exception of the three marks of which he speaks, as indicating the eyes and mouth of a face.

According to Hyde ("Persian Religion," p. 38), "Idolaters as well as sun-worshippers existed in ancient Persia, and the worhip of fire and that of idols were combined at one period."

Quintus Curtius, when describing the march of the army of Darius (writing, however, long after date), says :- "Darius was accompanied by an image of the sun, placed in a crystal, and the sacred fire carried on a silver altar."

The sun, which was regarded as a wheel, a store of gold, an eagle, was also styled the eye of Varuna. ${ }^{1}$ The worship of Mithra was likewise a worship of the sun; Mithra was the god of daylight. He and Varuna were fabled to journey at even in a brazen car. From this has probably arisen the horse-sun and the wheel-sun. Euripides gives the sun a winged car ; and, on coins from Eleusis, Dêmêtêr is represented riding in such a car drawn by two serpents.

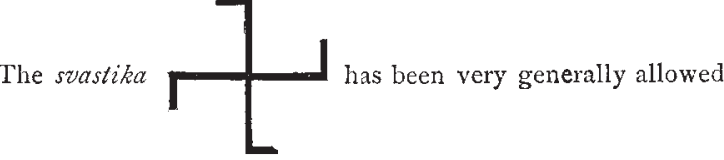

to be a symbol of Thor, who, to the Scandinavians, was the god of thunder and lightning and of the domestic hearth, and therefore of fire also. The arrows in the hand of Jove, the thunderer of Roman mythology, resemble somewhat a com pressed or crushed siastika. The above form of this symbot,

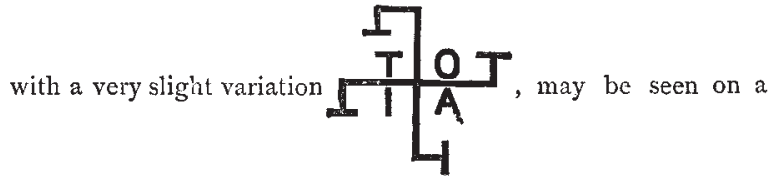

slab taken out of a Christian cutacomb in Naples, and now in the National Museum there. A very natural inference is, that this stone sealed the grave of one who had suffered martyrdom by fire.

The szastika has been held to be an emblem of fire, as being the way in which that element was first produced by primitive peoples - a method which is said to be in use in certain Hindu temples at the present day. It consists in two crooked sticks being laid one across the other, and a hole drilled through both; a pointed stick being there inserted, this is rapidly twirled by the hands until the five points of contact become ignited.

I To the Persians, Varuna was the god of the clouds and of the celestial sea. When this branch of the Aryans reached Southern. India, he there became to them the god of the earthly sea. Lo the Greeks he was Ouranos; and to the Germans and Anglo-Saxons, the eye of Woden. 
The ground-plan of some well-known Hindú temples in India is that of the Greek cross. The lightning, another of the attributes of Thor, the thunderer, from its zigzag course, may not unnaturally have been likened to a serpent. A Hermes, or torso, in the Museum at Arles, and labelled "A Statue of Mithra," shows that the serpent had its place in the celestial mythology of the ancients. "This figure is entwined in the folds of a buge serpent, and between these are sculptured the signs of the zodiac.

During the Bronze Age, which, as regards Scandinavia, Dr. Worsaae fixes at from about 500 B.C. to 100 1.D., the form of the svastika received several modifications : amongst others, it became what he styled the single $\mathrm{O}$, or the double thus, and also the three-armed figure 9 , or triskele. In

another place he says (ibid.): "Curiously enough, in the new Runic alphabet which.was adopted at this time (later Iron Age or Viking period), the letter $S$, which recalls one of the old sun symbols, was called Sol or Sun."

The connection of the triskele with the serpent may possibly seem to some far-fetched, but a tolerably certain proof that it is not so is shown in a bronze brooch found, a few years ago, when excavating the Roman camp on the Saalberg, near Frankfort-on-the-Maine. This ornament is now in the local Museum of Homburg-v.-d.-Hohe. Inclosed in a ring of bronze is a triskele; each arm has a distinct serpent's head; they all turn the same way, as, it may be observed, do the arms of the suastika (or Crux Gammata). The connection of this symbol with the serpent survived even down to the so called "cinque-cento" period. It survived in Christian times-under the name of the fylfot-even down to the fourteenth or fifteenth centuries, and is alluded to by Sir J. Gardner Wilkinson ("Dalmatia and Montenegro," vol. i. p. 23). He speaks of finding

this emblem, in the form of two snakes

"as a device upon some tombs in those provinces"; and adds :- "This symbol was used in early Christian times in England and other countries, among ornamental devices, in manuscripts, on tombs, and on church ornaments and vestments, from about IOII to I 400 A.D., after which it is not met with in England. It is very common on monumental crosses of the fourteenth century, and was a favourite ornament of the Greek Church, whence it probably came into England and Western Europe : it is known in heraldry as the fylfot."

In the treasury of the Cathedral at Valencia, in Spain, there are two richly embroidered altar frontals, which (as stated by the officials in charge) formerly belonged to the church of old St. Paul's, in London, having been sold into Spain by our King Henry VIII. The needlework is a triumph of art. On each of these frontals is represented a portion of the old church. On one of them-which depicts our Blessed Lord going to crucifixion-a soldier of the Roman army, or of one of their allies, is represented holding a pennant on which is a svastika of the fylfot type.

In this brief sketch I have endeavoured to show the relations between sun- and fire-worship, both of which may have existed contemporaneously amongst primitive peoples, since light and warmth were naturally highly prized by them.

The Greek cross, or cross of Savoy

the ring-cross of the later Stone Age), appears to be the earliest known form of that symbol. A form of svastika of the Bronze Age-the triskele-may still be traced in the trinacria of the arms of Sicily and the Manx-man of our isles.

Did space permit, much more could be said regarding the svastika as a pre-Christian and a Christian cross.

Great Brampton, Hereford

HARRIET G. M. MURRAY-AyNSIEY

\section{Important Points in the History of Earthquake Investigation in Japan}

As the various instruments for recording earthquakes which have been invented in Japan appear destined to play an important part in future seismometrical investigations, and as the authorship of many of these instruments has recently formed the subject of a discussion, in which, although my name has been freely used, my distance from Europe practically prevents me from taking part, and which, so far as I can see, can only result in confusing those who are unacquainted with the work done in Japan, I venture to $\mathrm{g} v \mathrm{v}$ the following notes as an outline of the more important points in the history of seismometry in this country.

In 1872, Dr: Verbeck, of Tokio, obtained approximate measurements of the range and direction of earthquake motion by mean; of an instrument consisting of a heavy slab resting on balls, the slab being the steady-point (Trans. Seis. Soc. vol. i. p. 23). The resemblance of this instrument to the lighthouse tables the invention of the late Mr. Stevenson is apparent.

In 1879 , results which were probably more accurate than those of Dr. Verbeck were published in the Transactions of the Seismological Society (vol. i. p. 91), and the residents in Japan were astonished to learn that the amplitude of what were apparently severe earthquakes were to be measured in millimetres and fractions of millimetres rather than in inches. The results were obtained partly by Dr. Wagener and partly by myself. I worked with pendulums writing their records by what I still find to be the most delicate kind of pointers upon the surface of smoked glass. Dr. Wagener used a pendulum which was practically "dead-beat," and a pointer which gave a multiplied representation of the earth's movement. This was the first time that the necessity of multiplying-levers was recognised.

Shortly after this I published examples of diagrams of earthquake motion obtained by allowing smoked glass plates, at the time of a disturbance, to move for a period of three or four seconds beneath the pointers of a pendulum. The diagrams were short, but the results obtained respecting period, amplitude, and quantities calculable from these data, have not been shown by subsequent investigations to have been unsatisfactory (Trans. Seis. Soc. vol, i. p. 9r, \&c.).

About this time Prof. Chaplin and Mr. T. Gray independently constructed bracket seismographs (Trans. Seis. Soc. vol. i. p. 25). Mr. Gray's bracket seismographs were never specially described, but they still exist in the Imperial College of Engineering. Mr. Gray's next invention was a torsion pendulum seismograph, which, being suspended from horizontal levers which in turn were held up by horizontally placed springs, also recorded vertical motion. A curious feature in this instrument was that the horizontal levers were so supported that for slight displacements they had a constant leverage. In the same paper describing this instrument, Mr. Gray emphasises the importance of having seismographs so constructed that the steady-point should be in neutral equilibrium (Trans. Seis. Soc. vol. i. p. 48).

The next advance was made by Prof. Ewing, who, by using a bracket seismograph with a pivoted weight and a multiplyinglever writing on a continuously moving plate, obtained diagrams which inasmuch as they extended over a considerable portion of time were superior to all that had preceded them.

This instrument was described in Europe and Japan withont the briefest mention of the fact that bracket seismographs, multiplying-levers, smoked glass plates, continuous records, \&c., had a previous existence. Two of such publications are before me (Trans. Asiatic Soc. of Japan, vol. ix. p. 4o, and Trans. Seis. Soc. vol. ii. p. 45).

At the time this excited no public comment, and it was not until Prof. Ewing distinctly claimed at least a joint authorship, not only of all bracket seismographs, but of all instruments which might involve the same principle, like the various forms of rolling spheres, rolling cylinders, conical pendulums, double brackets, \&c., the inventions of Mr. Gray, that discussions arose. For one of these discussions see Trans. Seic. Soc. vol. iii. p. 9.)

Although Mr. Gray distinctly stated that he had experimented with bracket seismographs prior to the one introduced by Prof. Ewing (Trans. Seis. Soc. vol. iii, p. 5), and aithough I personally acquainted Prof. Ewing with this fact, so far as I am aware Prof, Ewing has never in any manner whatever referred to this. Mr. Gray's seismograph for registering vertical motion, which in its principle was a new departure in seismometric methods, was constructed and described in April I88I (Trans. Seis. Soc. vol. iii. p. I37). 